\title{
Intravenous Immunoglobulin Contains Specific Antibodies Inhibitory to Activation of T Cells by Staphylococcal Toxin Superantigens
}

\author{
Syuji Takei, Yogesh K. Arora, * and Sharyn M. Walker** \\ Divisions of Rheumatology and *Research Immunology/Bone-Marrow Transplantation, Department of Pediatrics, Childrens Hospital \\ Los Angeles and ${ }^{\ddagger}$ Department of Microbiology, University of Southern California School of Medicine, Los Angeles, California 90027
}

\begin{abstract}
Superantigens are products of bacteria with dual affinity for HLA-DR and the variable region of the $\beta$ chain of the $T$ cell receptor, leading to the stimulation of large numbers of $T$ cells. Because there is evidence for the involvement of superantigens in various disease conditions in which intravenous IgG (IVIgG) is used as therapy, the purpose of the present study was to determine if IVIgG contains antibodies inhibitory to $T$ cell stimulation by the superantigens. ELISA and Western assays revealed high concentrations of antibodies in the pooled IgG against eight different staphylococcal toxin (Staph-toxin) superantigens. The IVIgG inhibited in vitro stimulation of human peripheral blood T cells by the Staph-toxins, but did not inhibit responses elicited by phytohemagglutinin or anti-CD3. Inhibition was mediated by Staph-toxin-specific antibodies as shown by affinity adsorption depletion studies. The antibodies functioned by inhibiting the binding and / or presentation of Staphtoxins by $\mathrm{DR}^{+}$accessory cells. In conclusion, this report is the first to show that normal pooled IgG contains antibodies against a major group of the superantigens, the Staph-toxins, and that the antibodies can inhibit Staph-toxin-elicited $T$ cell activation, suggesting a possible immunoregulatory role for the antibodies in vivo. (J. Clin. Invest. 1993. 91:602-607.) Key words: autoimmune disease $\bullet$ immunologic deficiency syndrome - immunotherapy
\end{abstract}

\section{Introduction}

Superantigens are a class of bacterially derived substances which stimulate a large fraction of the $T$ cell population without requiring previous sensitization ( $1-8)$. T cell stimulation is mediated by the dual affinity of superantigens for the class II major histocompatibility complex on accessory cells and for the relatively invariant sequence of the variable $(\mathrm{V}) \beta$ region of the $T$ cell receptor $(T C R)^{1}(1-8)$. Depending on the superanti-

Dr. Syuji Takei is on leave from the Department of Pediatrics, Faculty of Medicine, Kagoshima University, Kagoshima City, Japan.

Address reprint requests to Dr. Sharyn M. Walker, Box 62, Childrens Hospital Los Angeles, 4650 Sunset Blvd., Los Angeles, CA 90027.

Received for publication 19 February 1992 and in revised form 18 June 1992.

1. Abbreviations used in this paper: IVIgG, intravenous immunoglobulin G; SEB, staphylococcal enterotoxin B; SEE, staphylococcal enterotoxin E; Staph-toxins, staphylococcal toxins; TCR, T cell receptor; TSST-1, toxic shock syndrome toxin-1; V, variable.

\section{J. Clin. Invest.}

(C) The American Society for Clinical Investigation, Inc. 0021-9738/93/02/0602/06 \$2.00

Volume 91, February 1993, 602-607 gen, $T$ cells of different $V \beta$ families are stimulated $(2,8)$. The staphylococcal toxins (Staph-toxins) comprise a major group of superantigens which have been highly purified and well characterized in terms of their effects on $T$ cells $(3,8)$.

Superantigens may be involved in dysregulation of the immune system, contributing to a number of diverse diseases (915). The Staph-toxins have major effects on the immune system in vivo, causing the initial activation of large numbers of $T$ cells, resulting in the expansion of various $\mathrm{V} \beta \mathrm{T}$ cell families, followed by their anergy and deletion $(16,17)$. Superantigens have been implicated in the clonal expansion of $\mathrm{T}$ cells observed in toxic shock syndrome (11), rheumatoid arthritis (12), and Kawasaki disease (13) and in the deletion of T cells seen in human immunodeficiency virus (HIV) infection $(14,15)$.

Because superantigens may be involved in diseases in which intravenous IgG (IVIgG) is used as therapy (18-22), the present study was undertaken to determine whether or not IVIgG contained antibodies that inhibited $\mathrm{T}$ cell activation by the Staph-toxins. IVIgG is a pool of IgG derived from a large number of normal donors $(>6,000)(18-22)$, which can supply protective antibodies against infectious agents in immunocompromised individuals. The role of pooled IgG in abrogating symptoms in autoimmune diseases is less well established (18). The present study shows that pooled IgG contains high concentrations of Staph-toxin-specific antibodies which are highly inhibitory to the in vitro activation of $\mathrm{T}$ cells by the Staph-toxins.

\section{Methods}

Reagents and cell lines. Two pooled human IgG preparations were purchased for this study: pool 1, Venoglobulin I (Alpha Therapeutic Corp., Los Angeles, CA); and pool 2, Sandoglobulin (Sandoz Pharmaceutical Corp., East Hanover, NJ). Each preparation was from a different pool of at least 6,000 normal healthy adult donors within the United States. Pool 1 was used in all of the studies reported herein, except Table I in which both pools were used. Purified human monoclonal IgG ( $\operatorname{IgG}_{1}$ myeloma) was from Dr. H. Spiegelberg, Scripps Clinic and Research Foundation, La Jolla, CA. Fc and $F(a b)_{2}$ portions of pooled human IgG were purchased from Calbiochem-Behring Corp., La Jolla, CA.

All Staph-toxins except staphylococcal enterotoxin B (SEB) were purchased from Toxin Technology, Madison, WI. SEB was purchased from Sigma Chemical Co., St. Louis, MO. The toxins were $>95 \%$ pure as determined by sodium dodecyl sulfate (SDS)-polyacrylamide gel electrophoresis. Phytohemagglutinin-P (PHA) was from Difco Laboratories, Detroit, MI. Anti-CD3 monoclonal antibody 147.1.3 was kindly supplied by Dr. William Stohl, University of Southern California School of Medicine.

The Raji B cell line was from American Type Tissue Culture Collection, Rockville, MD, and the Jurkat $\mathrm{T}$ cell line (E6-1) was kindly provided by Dr. Arthur Weiss, University of California, San Francisco, CA. 
Measurement of antibodies to the Staph-toxins. The enzyme-linked immunosorbent assay (ELISA) was performed as described by Walker et al. (23). Assay wells were coated with $5 \mu \mathrm{g} / \mathrm{ml}(0.5 \mu \mathrm{g}$ per well) toxin. Pooled IgG preparations (adjusted to $10 \mathrm{mg} / \mathrm{ml}$ to approximate the normal serum IgG level) were diluted 1:1,000 or greater. Bound IgG was detected by addition of an affinity-purified $\mathrm{F}(\mathrm{ab})_{2}$ preparation of rabbit anti-human IgG specific for $\mathrm{Fc}$ and conjugated with peroxidase (Rockland, Inc., Gilbertsville, PA). Each dilution of pooled IgG was assayed in duplicate on nonantigen-coated (background) and antigen-coated wells; background values, which averaged $<0.010 \mathrm{OD}$, were subtracted from the antigen-coated well values. The concentration of antibody in each IgG preparation was defined as the reciprocal dilution of the sample giving an OD of 0.2 extrapolated from a standard curve. The relationship between absorbance and the dilution of IgG was linear on a log-log plot between an OD of 0.05 and 1.50 , with a similar slope of binding for each toxin (data not shown).

Western blot analysis. The various Staph-toxins $(0.3 \mu \mathrm{g})$ were separated electrophoretically on polyacrylamide (12\%) slab gels with SDS (Bio-Rad Laboratories, Richmond, CA). Pooled IgG was assayed at 20 $\mu \mathrm{g} / \mathrm{ml}$. Bound $\mathrm{IgG}$ was detected with the same peroxidase-labeled $\mathrm{IgG}$ specific antiserum used in the ELISA.

Affinity adsorption of SEB specific antibodies. SEB $(0.5 \mathrm{mg})$ was coupled to cyanogen bromide-activated Sepharose (24). $10 \mathrm{mg}$ of pooled IgG was adsorbed by mixing with the SEB-coupled Sepharose for $45 \mathrm{~min}$ at room temperature. The adsorbed IgG was removed by centrifugation, the adsorbent was washed six times, and the bound IgG was eluted with sodium thiocyanate ( $3 \mathrm{M}$ with $0.015 \mathrm{M}$ potassium phosphate buffer, $\mathrm{pH} 6.6$ ). The eluate was subsequently dialyzed and assayed for IgG concentration and for specific antibodies by ELISA.

Lymphoid cell preparation and culture. Peripheral blood lymphocytes were prepared by centrifugation of heparinized blood from normal individuals on Ficoll-Paque (Pharmacia, Inc., Piscataway, NJ). The purified lymphoid cells $\left(1 \times 10^{5}\right)$ were cultured at $37^{\circ} \mathrm{C}$ in $5 \%$ carbon dioxide in a round-bottomed, 96-well plate (Flow Labs, Inc., McLean, VA) in $0.2 \mathrm{ml}$ of culture medium. The culture medium consisted of RPMI-1640 with Hepes buffer $(10 \mathrm{mM}), 5 \%$ heat-inactivated fetal calf serum, antibiotics (penicillin [100 $\mathrm{U} / \mathrm{ml}]$, streptomycin [100 $\mu \mathrm{g} / \mathrm{ml}]$, and gentamicin $[20 \mu \mathrm{g} / \mathrm{ml}])$, glutamine ( $2 \mathrm{mM})$, and 2-mercaptoethanol $\left(5 \times 10^{-5} \mathrm{M}\right)$. The various toxins and pooled $\mathrm{IgG}$ were added $1 \mathrm{~h}$ before addition of the lymphoid cells to allow time for antigen-antibody formation. Proliferation was assessed $3 \mathrm{~d}$ later by pulsing with tritiated thymidine for $6 \mathrm{~h}$.

Interleukin 2 (IL-2) assay. IL-2 was assayed on the IL-2-dependent murine CTLL cell line (25). One unit of IL-2 was defined as that amount of IL-2 which gave half of the maximal proliferation induced by $100 \mathrm{U}$ of recombinant IL-2/ml.

Data calculations. Data are presented as the mean of duplicate or triplicate determinations with the standard deviation (SD). Each experiment is representative of experiments performed at least three times.

\section{Results}

IgG antibodies to Staph-toxins in IV (pooled) IgG. The concentrations of IgG antibodies to eight Staph-toxins in human IgG from two different donor pools of $\mathrm{IgG}$ were measured by ELISA. Table I shows that the two pooled IgG preparations contained high concentrations of antibodies to the various toxins, with a near identical concentration profile for each pool. Antibody concentrations are expressed as the reciprocal of the highest dilution of the IgG (original concentration of $10 \mathrm{mg}$ / $\mathrm{ml}$ ) giving an absorbance of 0.2 . For example, pool 1 was positive to a dilution of $1: 15,400$ for SEB and 1:3,600 for SEE. Pool 1 was used in all subsequent studies.

Western blot analysis was performed to establish that IgG
Table I. Binding of Pooled IgG to the Staph-toxins

\begin{tabular}{lrc}
\hline & \multicolumn{2}{c}{ Reciprocal dilution } \\
\cline { 2 - 3 } Toxin & \multicolumn{3}{c}{ Pool 1 } & Pool 2 \\
\hline \multicolumn{3}{c}{$30^{-3}$} \\
SEA & $3.9 \pm 0.4$ & $2.6 \pm 0$ \\
SEB & $15.4 \pm 2.2$ & $12.7 \pm 0.2$ \\
SEC1 & $15.1 \pm 4.4$ & $13.9 \pm 1.0$ \\
SEC2 & $20.3 \pm 3.0$ & $20.6 \pm 1.0$ \\
SEC3 & $14.8 \pm 5.1$ & $12.2 \pm 0.5$ \\
SEE & $3.6 \pm 0.9$ & $5.9 \pm 1.6$ \\
Exfol & $8.5 \pm 2.0$ & $18.7 \pm 4.3$ \\
TSST-1 & $11.4 \pm 2.7$ & $15.7 \pm 0.1$ \\
& & \\
\hline
\end{tabular}

The concentration of IgG antibodies in pooled IgG to the various toxins was determined by ELISA. The pooled IgG was adjusted to a concentration of $10 \mathrm{mg} / \mathrm{ml}$, the approximate concentration of $\mathrm{IgG}$ in normal human serum. The reciprocal dilution of pooled IgG which was positive at an absorbance of $0.2 \mathrm{OD}$ after subtraction of the background defined the concentration of antibody to the various toxins. Values $( \pm \mathrm{SD})$ were determined by extrapolation from a standard curve (Methods).

binding was directed against the Staph-toxins. Fig. 1 shows that pooled IgG bound predominantly to proteins in the $20-30 \mathrm{kD}$ range, the approximate molecular weights of the Staph-toxins $(2,26)$. In the case of exfoliative toxin (Exfol), the IgG bound to additional proteins, but the majority of the binding was in the $29-\mathrm{kD}$ area.

Specificity of binding. Experiments were performed to ensure that binding by the pooled IgG to the Staph-toxins was mediated by specific antibody. Table II shows that an $\mathrm{F}(\mathrm{ab})_{2}$ preparation of pooled IgG bound to the toxins as strongly as did whole IgG (Table I), whereas binding of an Fc fragment preparation and monoclonal IgG was minimal. The above background binding to some of the toxins by Fc fragment and monoclonal IgG may have been due to a minor contamination of the Staph-toxins with protein A, an Fc binding and V heavy chain III binding protein from Staphylococcus aureus (27).

Table II also demonstrates that binding.by the pooled IgG was toxin specific. Pooled IgG which had been adsorbed on SEB-coupled Sepharose was essentially depleted of binding to SEB, while binding to toxic shock syndrome toxin-1 (TSST-1) was retained. In addition, IgG eluted from the SEB-adsorbent bound specifically to SEB and minimally to TSST-1 (data not shown). In competitive inhibition studies not shown here, addition of soluble SEB blocked binding by pooled IgG to bound SEB in the ELISA, but did not block binding to TSST-1. Others have shown that antibodies to SEB and TSST-1 are not crossreactive (28). Taken together, these experiments demonstrate that pooled IgG contains Staph-toxin-specific antibodies.

Inhibition of Staph-toxin-elicited $T$ cell proliferation by pooled IgG. The ability of pooled IgG to inhibit human T cell proliferation in response to SEB and TSST-1 was examined. Fig. 2 shows that pooled IgG significantly inhibited proliferation by these two toxins. Inhibition was greatest at the lower toxin concentrations. Fig. 2 also shows that the pooled IgG was not nonspecifically inhibitory, in as much as stimulation of $\mathrm{T}$ cells with anti-CD3 or PHA was not inhibited. 


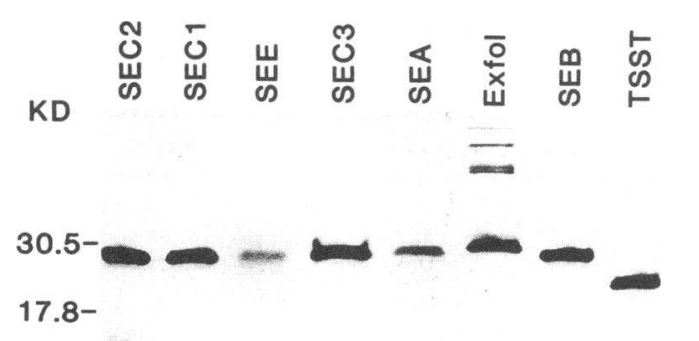

Figure 1. Binding of pooled IgG to the Staph-toxins as assayed by Western blot. The Staph-toxins $(0.3 \mu \mathrm{g})$ were electrophoresed, transferred to nitrocellulose, and exposed to $20 \mu \mathrm{g} / \mathrm{ml}$ of pooled IgG. The bound IgG was developed with IgG-specific antiserum used in the ELISA. Molecular mass markers are noted on the left of the figure, followed by lanes containing Staph-toxins SEC2, SEC1, SEE, SEC3, SEA, Exfoliative toxin, SEB, and TSST-1.

Inhibition by specific antibodies. To determine whether or not inhibition of $T$ cell proliferation was mediated by specific antibodies, we first examined whether inhibition was mediated by the Fab region of the pooled IgG. Fig. 3 (top panel) shows that the $F(a b)_{2}$ preparation of pooled IgG inhibited $T$ cell activation by SEB to a similar degree as whole pooled IgG, whereas the Fc fragment of pooled IgG was not inhibitory. Fig. 3 (bottom panel) also shows that the monoclonal IgG, which lacked antibodies to the Staph-toxins ( Table II), was not inhibitory to Staph-toxin-elicited proliferation, even at a relatively high concentration $(1 \mathrm{mg} / \mathrm{ml})$.

Inhibition by Staph-toxin-specific antibodies. Fig. 4 shows that pooled IgG depleted of SEB-specific antibodies lost most of its ability to inhibit $T$ cell activation by SEB, but retained the ability to inhibit the response to TSST-1. In contrast, antibodies eluted from the SEB adsorbent were strongly inhibitory to the SEB response, but not to the TSST-1 response. The eluted

Table II. Specificity of IgG Binding to the Staph-toxins

\begin{tabular}{lrlll}
\hline & \multicolumn{4}{c}{ Reciprocal dilution } \\
\cline { 2 - 5 } Toxin & $\begin{array}{c}\mathrm{F}(\mathrm{ab})_{2} \\
\text { fragment }\end{array}$ & $\begin{array}{c}\text { Fc } \\
\text { fragment }\end{array}$ & $\begin{array}{c}\text { Monoclonal } \\
\text { IgG }\end{array}$ & $\begin{array}{c}\text { Pooled IgG } \\
\text { adsorbed } \\
\text { on SEB }\end{array}$ \\
\hline & \multicolumn{5}{c}{$\times 10^{-3}$} \\
SEA & $3.2 \pm 0.1$ & $0.4 \pm 0$ & $0.8 \pm 0$ & \\
SEB & $13.7 \pm 0.2$ & $0.1 \pm 0$ & $0.0 \pm 0$ & $1.3 \pm 0$ \\
SEC1 & $9.6 \pm 0.6$ & $0.3 \pm 0.1$ & $0.9 \pm 0.1$ & \\
SEC2 & $19.0 \pm 0.1$ & $0.1 \pm 0.1$ & $0.4 \pm 0.1$ & \\
SEC3 & $12.9 \pm 0.5$ & $0.1 \pm 0$ & $0.4 \pm 0.1$ & \\
SEE & $3.0 \pm 0.2$ & $0.0 \pm 0$ & $0.1 \pm 0.1$ & \\
Exfol & $7.5 \pm 0.9$ & $0.1 \pm 0$ & $0.0 \pm 0$ & \\
TSST-1 & $12.4 \pm 1.0$ & $0.2 \pm 0$ & $0.0 \pm 0$ & $9.1 \pm 0$ \\
& & & & \\
\hline
\end{tabular}

$\mathrm{F}(\mathrm{ab})_{2}$ and $\mathrm{Fc}$ fragments of pooled IgG, a monoclonal (human myeloma) IgG, and pooled IgG which had been passed over an SEB affinity adsorbent column were assayed by ELISA for binding to the toxins. The reciprocal dilution of each preparation (original concentration of $10 \mathrm{mg} / \mathrm{ml}$ ) giving an absorbance of 0.2 is shown. Values are \pm SD.

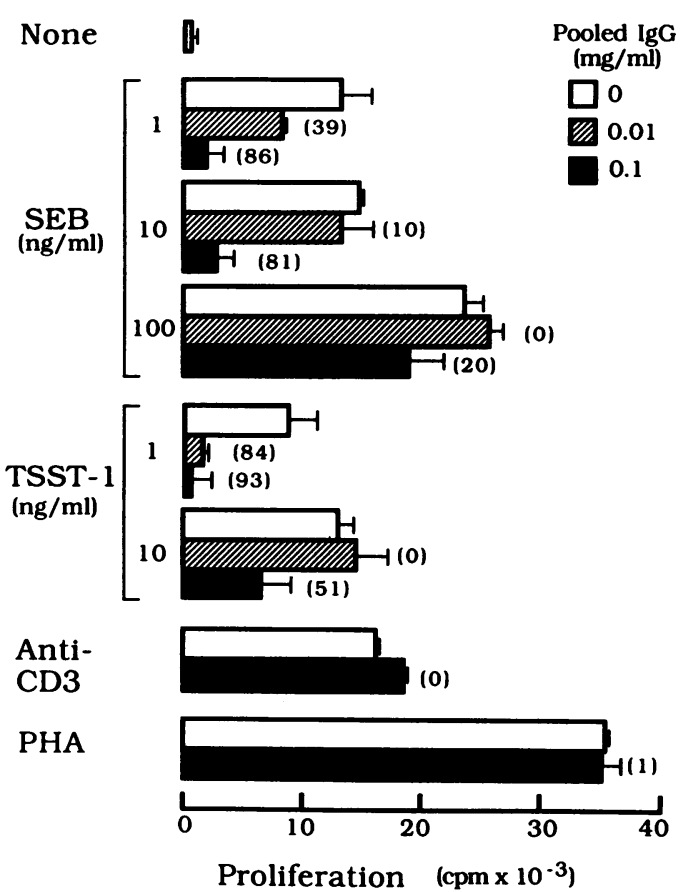

Figure 2. Inhibition of Staph-toxin-elicited T cell proliferation by pooled IgG. Varying concentrations of pooled IgG were preincubated for $1 \mathrm{~h}$ with SEB, TSST-1, anti-CD3 ( $100 \mathrm{ng} / \mathrm{ml})$, or PHA. Human mononuclear cells were then added and proliferation was measured 3 $d$ later. Percent inhibition of $\mathrm{T}$ cell proliferation by the pooled IgG is noted above the bars in parentheses.

antibodies were inhibitory in nanogram concentrations, showing a significant increase in specific inhibitory activity. Thus, Staph-toxin specific antibodies appear to mediate the inhibition by pooled IgG.

Cell site of inhibition. Because proliferation is a relatively late event in T cell activation, the effect of pooled IgG on an earlier event, the production of IL-2, was examined. Table III shows that IL-2 production in response to SEB was inhibited by pooled IgG to the essentially same extent as proliferation.

The inhibition of IL-2 production suggested that antibodies in pooled IgG blocked SEB directly, making it unavailable to the $T$ cells. To determine if pooled IgG interfered with binding of the Staph-toxins to antigen-presenting cells, SEB was allowed to bind at $4{ }^{\circ} \mathrm{C}$ to the lymphoid cells with and without pooled IgG present. The cells were then washed and assayed for proliferation $3 \mathrm{~d}$ later. Table IV shows that when SEB and IgG were added together, there was marked inhibition of $T$ cell proliferation ( $71 \%$ inhibition). The table also shows that pretreating the lymphoid cells with IgG before addition of SEB did not inhibit subsequent $T$ cell proliferation (lines 3 and 4 ). Thus, the antibodies were not inhibitory by a direct effect (e.g., anti-idiotype) on the lymphoid cell themselves.

The second experiment in Table IV examined the effect of pooled IgG on presentation of the staphylococcal enterotoxin $\mathrm{E}$ (SEE) to the Jurkat $\mathrm{T}$ cell line by the $\mathrm{DR}^{+}$Raji accessory cell line. The Jurkat T cell line produces IL-2 in response to SEE when presented on Raji accessory cells (29). The table shows that the pooled IgG significantly inhibited the ability of the Raji cells to present SEE to the Jurkat T cells. In summary, the experiments in Table IV show that pooled IgG inhibits primar- 


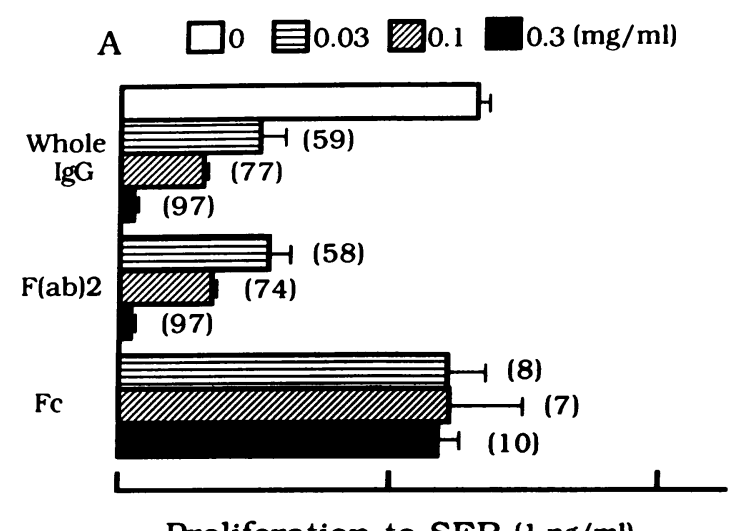

Proliferation to SEB (1 ng/ml)

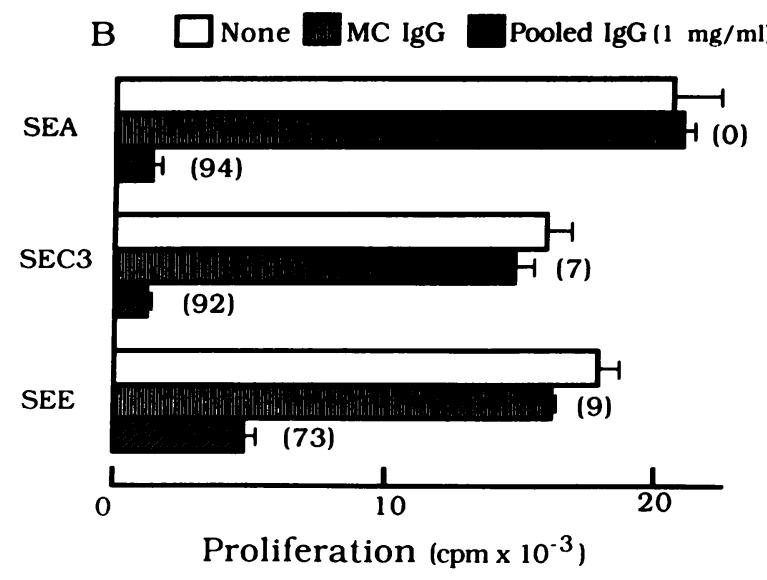

Figure 3. Ability of various IgG preparations to inhibit the proliferative response to the Staph-toxins. Varying concentrations of pooled $\mathrm{IgG}$, an $\mathrm{F}(\mathrm{ab})_{2}$ preparation of pooled IgG, an Fc preparation of pooled $\mathrm{IgG}$ (top panel) and $1 \mathrm{mg} / \mathrm{ml}$ of monoclonal $(M C) \mathrm{IgG}$ (bottom panel) were compared for their ability to inhibit $\mathrm{T}$ cell proliferation in response to the Staph-toxins ( $1 \mathrm{ng} / \mathrm{ml}$, except for SEE which was $0.1 \mathrm{ng} / \mathrm{ml}$ ).

ily through inhibition of binding and/or presentation of the Staph-toxins by accessory cells.

\section{Discussion}

The present study demonstrates that IVIgG inhibits the in vitro stimulation of T cells by Staph-toxin superantigens. High concentrations of antibodies to the Staph-toxins were present in the pooled IgG. Inhibition was mediated by Staph-toxin-specific antibodies; this was shown most definitively by the relative inability of pooled IgG depleted of SEB-specific antibodies to inhibit the response to SEB, while retaining the ability to inhibit the response to the antigenically unrelated TSST-1.

The primary mechanism of inhibition by pooled IgG was interference with accessory cell presentation of specific Staphtoxins to the T cells. Pooled IgG blocked the binding and/or presentation of SEB and SEE by accessory cells. Blockade may have been mediated by antibodies directed against epitopes on SEB and SEE which are required for binding to HLA-DR. Polyclonal rabbit antisera generated against specific epitopes on SEA have been shown to inhibit SEA binding to HLADR (30).
Several mechanisms have been proposed to explain the immunomodulatory effects of IVIgG, including antigen-specific antibodies, anti-idiotypic antibodies, and nonspecific blockade of Fc receptors (18-22). In the present study the ability of pooled IgG to inhibit Staph-toxin elicited T cell activation was not mediated nonspecifically through the $\mathrm{Fc}$ region of $\mathrm{IgG}$, as shown by the lack of inhibition by monoclonal IgG and the ability of the $F(a b)_{2}$ fraction of pooled IgG to be as inhibitory as whole pooled IgG. We did not observe inhibition by possible anti-idiotypic antibodies in IVIgG directed against the TCR, for example, inasmuch as lymphoid cells preincubated with pooled IgG responded normally to the Staph-toxins. Rather, inhibition was mediated directly by Staph-toxin-specific antibodies. Notably, the ability of $F(a b)_{2}$ antibodies to inhibit Staph-toxin-elicited $T$ cell stimulation suggests that inhibition of superantigen responses by specific antibodies may be different from inhibition of antigen-specific responses, in which the Fc portion is required (31).

The presence of antibodies to the Staph-toxins in IVIgG shows that normal individuals are naturally exposed to the Staph-toxins. With age normal individuals exhibit an increasing prevalence of serum antibodies to the Staph-toxins ( 28,32 , 33 , unpublished observation), especially to TSST -1 ( $>90 \%)$ $(28,32,33)$. Clinical infections with Staphylococcus aureus result in a higher prevalence and concentration of antibodies to the Staph-toxins $(34,35)$. Immunocompromised individuals may be exposed to higher concentrations of the Staph-toxins than normal individuals. For example, HIV-infected individuals have a higher incidence of nasal colonization with Staphy-

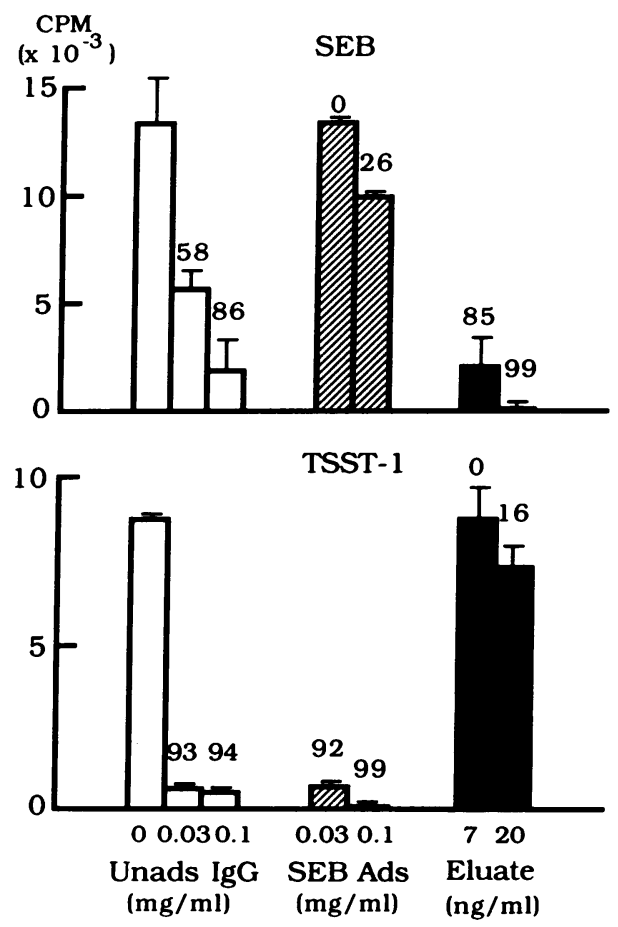

Figure 4. Effect of affinity-adsorbed IgG on the T cell response to SEB and TSST-1. Pooled IgG was adsorbed on SEB-coupled Sepharose and the depleted IgG and the eluate were assayed for their ability to inhibit the T cell proliferative response to SEB $(1 \mathrm{ng} / \mathrm{ml}$ ) (upper panel) and to the antigenically unrelated TSST-1 $(1 \mathrm{ng} / \mathrm{ml})($ lower panel). 
lococcus aureus and catheter-related bacteremias than immunocompetent individuals $(36,37)$.

Protection against $\mathrm{T}$ cell activation by antibodies to the Staph-toxins could be beneficial in HIV infection. T cells from asymptomatic HIV-infected individuals have been shown to undergo apoptosis upon exposure to SEB in vitro (15). If apoptosis occurs in vivo, significant $T$ cell loss would result. Furthermore, activation of $\mathrm{T}$ cells by the Staph-toxins could increase HIV replication, in that HIV replicates most effectively in activated T cells ( 38 ). Thus, pooled IgG, which is efficacious in the treatment of children infected with HIV (22), could protect not only against opportunistic infections, but also against activation of $\mathrm{T}$ cells through augmenting the levels of Staph-toxininhibitory antibodies.

The presence of antibodies to the Staph-toxin superantigens in pooled IgG raises the possibility of the presence of antibodies to other endogenous superantigens, such as those produced by streptococcal $(3,39)$ and mycoplasma organisms (40), as well as other superantigens to which humans may be exposed. Because of an increased presence of certain $\mathrm{V} \beta$ TCR families in autoimmune diseases $(9,12,13)$ and because superantigens are the only substances known to activate $\mathrm{V} \beta \mathrm{T}$ cell families selectively ( 3 ), superantigens have been implicated as etiologic and/or secondary agents in autoimmune disease (9). For example, excessive cytokine production by superantigenactivated $T$ cells (1) may exacerbate autoimmune diseases by providing help for autoreactive $T$ and $B$ cells (10). Thus, if superantigens are involved in autoimmune disease, superantigen specific antibodies could play a significant immunoregulatory role.

In conclusion, the mechanism(s) of IVIgG efficacy in a number of diverse disease conditions including Kawasaki disease, idiopathic thrombocytic purpura, systemic juvenile rheumatoid arthritis and HIV infection remains uncertain (18-22). However, we believe that the present study showing the ability of antibodies to the Staph-toxins to inhibit T cell activation by these superantigens provides a new insight into further study of the effectiveness of IVIgG in the treatment of disease.

Table III. Inhibition of IL-2 Production by Pooled IgG in Response to $S E B$

\begin{tabular}{rrrrrr}
\hline & \multicolumn{2}{c}{ IL-2 } & & \multicolumn{2}{c}{ Proliferation } \\
\cline { 2 - 3 } \cline { 5 - 6 } SEB & & $\begin{array}{r}\text { Pooled IgG } \\
(0.1 \mathrm{mg} / \mathrm{ml})\end{array}$ & & - & $\begin{array}{r}\text { Pooled IgG } \\
(0.1 \mathrm{mg} / \mathrm{ml})\end{array}$ \\
\hline$n g / m l$ & & $U / m l$ & & $c p m \times 10^{-3}$ \\
& & $<1$ & & \\
0 & $<1$ & $<1(>80)$ & & 5.5 & 0.5 \\
1 & $5 \pm 0$ & $3 \pm 0(77)$ & 7.6 & $1.6(79)$ \\
10 & $13 \pm 1$ & $11 \pm 0(21)$ & 12.1 & $9.8(19)$ \\
100 & $14 \pm 0$ & & & \\
\hline
\end{tabular}

Lymphocytes $\left(1 \times 10^{5}\right)$ were cultured with varying concentrations of SEB with and without pooled IgG. After $24 \mathrm{~h}$, part of the supernatant was removed for assay of IL-2 concentration. One unit of IL- 2 was $50 \%$ of the maximum proliferative response to recombinant IL-2 $(48,100 \mathrm{cpm}) .3 \mathrm{~d}$ after culture initiation the cells were pulsed with tritiated thymidine to determine the extent of proliferation (background cpm have been subtracted). Percent inhibition by pooled IgG is shown in parentheses. Values for IL-2 are $\pm \mathrm{SD}$.
Table IV. Cellular Site of Pooled IgG-mediated Inhibition

\begin{tabular}{|c|c|c|c|}
\hline Expt. & Cells & & $\begin{array}{l}\text { Percent } \\
\text { inhibition }\end{array}$ \\
\hline & & cpm & \\
\hline \multirow[t]{5}{*}{1} & PBMC treated with SEB, wash & $6,285 \pm 292$ & \\
\hline & $\begin{array}{l}\text { PBMC treated with SEB and } \\
\text { IgG, wash }\end{array}$ & $1,813 \pm 195$ & 71 \\
\hline & PBMC + SEB & $7,087 \pm 772$ & \\
\hline & $\begin{array}{l}\text { PBMC treated with IgG, wash, } \\
\text { add SEB }\end{array}$ & $8,002 \pm 1,250$ & 0 \\
\hline & PBMC alone & $276 \pm 61$ & \\
\hline \multirow[t]{3}{*}{2} & Jurkat + Raji treated with SEE & $33,800 \pm 3,480$ & \\
\hline & $\begin{array}{l}\text { Jurkat + Raji treated with SEE } \\
\text { and IgG }\end{array}$ & $10,380 \pm 4,440$ & 69 \\
\hline & Jurkat + Raji & $160 \pm 16$ & \\
\hline
\end{tabular}

In the first experiment to assess the ability of pooled IgG to block binding of SEB by accessory cells in peripheral blood mononuclear cells (PBMC), the lymphoid cells were treated for $35 \mathrm{~min}$ at $4^{\circ} \mathrm{C}$ with SEB $(10 \mathrm{ng} / \mathrm{ml})$ or pooled IgG $(0.3 \mathrm{mg} / \mathrm{ml})$ as indicated to allow time for the SEB to bind to $\mathrm{DR}^{+}$accessory cells within the lymphoid cell population. The lymphoid cells were then washed three times and cultured for $3 \mathrm{~d}$, and proliferation was measured (lines 1 and 2). Controls for the possible nonspecific inhibitory effects of the pooled IgG on the lymphoid cells directly are also shown (lines 3 and 4). Percent inhibition was calculated relative to the appropriate control responses without pooled IgG present. In the second experiment Raji $B$ accessory cells were treated with SEE $(10 \mathrm{ng} / \mathrm{ml})$ with and without pooled $\mathrm{IgG}(10 \mathrm{mg} / \mathrm{ml})$ present for $35 \mathrm{~min}$ at $4^{\circ} \mathrm{C}$. The treated cells were then washed three times and added $\left(1 \times 10^{4}\right)$ to the Jurkat $\mathrm{T}$ cell line $\left(4 \times 10^{4}\right)$ to determine if the Raji cells could present SEE. After $24 \mathrm{~h}$ the supernatant fluids were assayed for IL-2 by measuring the proliferation of the IL-2-dependent CTLL line. Previous control experiments showed no inhibition by preincubation of either the Raji or Jurkat T cell lines with pooled IgG followed by washing and addition of SEE (data not shown).

\section{Acknowledgments}

This work was supported in part by the Southern California Chapter of the Arthritis Foundation, the Wright Foundation, and the Berger Foundation.

\section{References}

1. Carlsson, R., and H. O. Sjögren. 1985. Kinetics of IL-2 and interferongamma production, expression of IL-2 receptors, and cell proliferation in human mononuclear cells exposed to staphylococcal enterotoxin A. Cell. Immunol. 96:175-183.

2. Fleischer, B. A conserved mechanism of $\mathrm{T}$ lymphocyte stimulation by microbial exotoxins. 1989. Microbial Pathol. 7:79-83.

3. Marrack, P., and J. Kappler. 1990. The staphylococcal enterotoxins and their relatives. Science (Wash. DC). 248:705-711.

4. Mollick, J. A., R. G. Cook, and R. R. Rich. 1989. Class II MHC molecules are specific receptors for staphyloccocal enterotoxin A. Science (Wash. DC). 244:817-820.

5. Fraser, D. R. 1989. High affinity binding of staphyloccocal enterotoxins A and B to HLA-DR. Nature (Lond.).339:221-223.

6. Gascoigne, N. R., and K. T. Ames. 1991. Direct binding of secreted T-cell receptor beta chain to superantigen associated with class II histocompatibility complex protein. Proc. Natl. Acad. Sci. USA 88:613-616.

7. Pontzer, C. H., J. K. Russel, and H. M. Johnson. 1991. Structural basis for differential binding of staphyloccocal enterotoxin $A$ and toxic shock syndrome toxin 1 to class II major histocompatibility molecules. Proc. Natl. Acad. Sci. USA 88:125-128. 
8. Kappler, J., B. Kotzin, L. Herron, E. W. Gelfand, R. D. Bigler, A. Boylston, S. Carrel, D. N. Posnett, Y. Choi, and P. Marrack. 1989. VB-specific stimulation of human T cells by staphylococcal toxins. Science (Wash. DC). 244:811-813.

9. Drake, C. G., and B. L. Kotzin. 1992. Superantigens: biology, immunology, and potential role in disease. J. Clin. Immunol. 12:149-162.

10. Friedman, S. M., D. N. Posnett, J. R. Tumang, B. C. Cole, and M. K. Crow. 1991. A potential role for microbial superantigens in the pathogenesis of systemic autoimmune disease. Arthritis Rheum. 34:468-480.

11. Cyoi, Y., J. A. Lafferty, J. R. Clements, J. K. Todd, E. W. Gelfand, J. Kappler, P. Marrack, and B. Kotzin. 1990. Selective expansion of T cells expressing V beta 2 in toxic shock syndrome. J. Exp. Med. 172:981-984.

12. Paliard, X., S. G. West, J. A. Lafferty, J. R. Clements, J. W. Kappler, P. Marrack, and B. L. Kotzin. 1991. Evidence for the effects of a superantigen in rheumatoid arthritis. Science (Wash. DC). 253:325-329.

13. Abe, J., B. L. Kotzin, K. Jujo, M. E. Melish, M. P. Glode, T. Kohsaka, and D. Y. Leung. 1992. Selective expansion of T cells expressing T-cell receptor variable regions $\mathrm{V}$ beta 2 and $\mathrm{V}$ beta 8 in Kawasaki disease. 1992. Proc. Natl. Acad. Sci. USA. 89:4066-4070.

14. Imberti, L., A. Sottini, A. Bettinardi, M. Puoti, and D. Primi. 1991. Selective depletion in HIV infection of $\mathrm{T}$ cells that bear specific $\mathrm{T}$ cell receptor $\mathrm{V}$ beta sequences. Science (Wash. DC). 254:860-862.

15. Groux, H., G. Torpier, D. Monte, Y. Mouton, A. Capron, and J. C. Ameisen. 1992. Activation-induced death by apoptosis in $\mathrm{CD4}^{+} \mathrm{T}$ cells from human immunodeficiency virus-infected asymptomatic individuals. J. Exp. Med. 175:331-340.

16. Rellahan, B. L., L. A. Jones, A. M. Kruisbeek, A. M. Fry, and L. A. Matis 1990. In vivo induction of anergy in peripheral $\mathrm{V}$ beta 8 positive $\mathrm{T}$ cells by staphyloccocal enterotoxin B. J. Exp. Med. 172:1091-1100.

17. MacDonald, H. R., S. Baschieri, and R. Lees. 1991. Clonal expansion precedes anergy and death of $\mathrm{V}$ beta $8+$ peripheral $\mathrm{T}$ cells responding to staphylococcal enterotoxin B in vitro. Eur. J. Immunol. 21:1963-1966.

18. Dwyer, J. M. 1992. Drug therapy: manipulating the immune system with immune globulin. N. Engl. J. Med. 326:107-116.

19. Newburger, J. W., M. Takahashi, J. C. Burns, A. S. Beiser, K. J. Chung, C. E. Duffy, M. P. Glode, W. H. Mason, V. Reddy, S. P. Sanders, et al. 1986. The treatment of Kawasaki syndrome with intravenous gammaglobulin. $N$. Engl. J. Med. 315:341-347.

20. Silverman, E. D., R. M. Laxer, M. Greenwald, E. Gelfand, A. Shore, L. D. Stein, and C. M. Roifman. 1990. Intravenous gamma globulin therapy in systemic juvenile rheumatoid arthritis. Arthritis Rheum. 33:1015-1022.

21. Imbach, P., S. Barundun, H. Cottier, E. Gugler, A. Hassig, A. Morell, H. Wagner, and H. Heiniger. 1990. Immunomodulation by intravenous immunoglobulin. Am. J. Pediatr. Hematol. Oncol. 12:134-140.

22. The National Institute of Child Health and Human Development Intravenous Immunoglobulin Study Group. 1991. Intravenous immune globulin for the prevention of bacterial infections in children with symptomatic human immunodeficiency virus infection. N. Engl. J. Med. 325:73-80.

23. Walker, S. M., B. Shaham, D. K. McCurdy, H. Wietting, Y. K. Arora, V. Hanson, and B. H. Bernstein. 1990. Prevalence and concentration of IgM rheumatoid factor in polyarticular onset disease as compared to systemic or pauciarticular onset disease in active juvenile rheumatoid arthritis as measured by ELISA. J. Rheumatol. 17:936-940.

24. Lee, A. C.-M., R. N. Robbins, and M. S. Bergdoll. 1978. Isolation of specific and common antibodies to staphylococcal enterotoxins $A$ and $E$ by affinity chromatography. Infect. Immun. 21:387-391.

25. Gillis, S., M. M. Fern, W. Ou, and K. A. Smith. 1978. T cell growth factor parameters of production and a quantitative microassay for activity. J. Immunol. 120:2027-2032

26. Bergdoll, M. S., I. Y. Huang, and E. J. Schantz. 1974. Chemistry of the staphylococcal enterotoxins. J. Agric. Food Chem. 22:9-13.

27. Sasso, E. H., G. J. Silverman, and M. Mannik. 1991. Human IgA and IgG $\mathrm{F}\left(\mathrm{ab}^{\prime}\right) 2$ that bind to staphylococcal protein A belong to the $\mathrm{V}_{\mathrm{H}}$ III subgroup. $J$. Immunol. 147:1877-1883.

28. Vergeront, J. M., S. J. Stolz, B. A. Crass, D. B. Nelson, J. P. Davis, and M. S. Bergdoll. 1983. Prevalence of serum antibody to staphylococcal enterotoxin $\mathrm{F}$ among Wisconsin residents: implications for toxic-shock syndrome. $J$. Infect. Dis. 148:692-698.

29. Fleischer, B., R. Gerardy-Schahn, B. Metzroth, S. Carrel, D. Gerlach, and W. Kohler. 1991. An evolutionary conserved mechanism of T cell activation by microbial toxins: evidence for different affinities of $\mathrm{T}$ cell receptor-toxin interaction. J. Immunol. 146:11-17.

30. Griggs, N. D., C. H. Pontzer, M. A. Jarpe, and H. M. Johnson. 1992. Mapping of multiple binding domains of the superantigen staphylococcal enterotoxin A for HLA. J. Immunol. 148:2516-2521.

31. Heyman, B., M. Rose, and W. O. Weigle. 1985. Carbohydrate chains on IgG2b: a requirement for efficient feedback immunosuppression. J. Immunol. 134:4018-4023.

32. Notermans, S., W. J. V. Leeuwen, J. Dufrenne, and P. D. Tips. 1983. Serum antibodies to enterotoxins produced by Staphylococcus aureus with special reference to enterotoxin F and toxic shock syndrome. J. Clin. Microbiol. 18:1055-1060.

33. Schröder, E., G. Kunstmann, H. Hasbach, and G. Pulverer. 1988. Prevalence of serum antibodies to toxic-shock-syndrome-toxin-1 and to staphylococcal enterotoxins A, B and C in West-Germany. Zentralbl. Bakteriol. Mikrobiol. Hyg. A. 270:110-114.

34. Kunstmann, G., E. Schröder, H. Hasbach, and G. Pulverer. 1989. Immune response to toxic-shock-syndrome toxin-1 (TSST-1) and to staphylococcal enterotoxins A, B and C in Staphylococcus aureus infections. Zentralbl. Bakteriol. 271:486-492.

35. Jozefczyk, Z. 1974. Specific human antibodies to enterotoxin A, B and C of staphylococcus: their increased synthesis in staphylococcal infection. J. Infect. Dis. 130:1-7.

36. Raviglione, M. C., P. Mariuz, A. Pablos-Mendez, R. Battan, P. Ottuso, and A. Taranta. 1990. High Staphylococcus aureus nasal carriage rate in patients with acquired immunodeficiency syndrome or AIDS-related complex. Am. $J$. Infect. Control. 18:64-69 (erratum in 1990. Am. J. Infect. Control. 18:268).

37. Northfelt, D. W., and B. Polsky. 1991. Bacteremia in persons with HIV infection. AIDS Clin. Rev. p.59-79.

38. NIH conference: Fauci, A. S., moderator. 1991. Immunopathogenic mechanisms in human immunodeficiency virus (HIV) infection. Ann. Intern. Med. 114:678-693.

39. Tomai, M. M., M. Kotb, G. Majumdar, and E. H. Beachey. 1990. Superantigenic properties of streptococcal M protein. J. Exp. Med. 172:359-362.

40. Matthes, M., H. Schrezenmeier, J. Homfeld, S. Fleischer, B. Malissen, H. Kirchner, and B. Fleischer. 1988. Clonal analysis of human T cell activation by the Mycoplasma arthritidis mitogen (MAS). Eur. J. Immunol. 18:1733-1737. 